\title{
FIRREA'S DAMAGE PROVISIONS: INEQUITABLE, UNNECESSARY, AND COSTLY TO BOOT
}

\author{
Carol Anne Sennello
}

\section{INTRODUCTION}

In 1989, Congress responded to the growing insolvency of the savings and loan (S\&L) industry with the passage of the Financial Institutions Reform, Recovery, and Enforceinent Act (FIRREA) of 1989. ${ }^{1}$ With a third of the S\&L industry operating at a loss and the number of insolvencies expected to grow, ${ }^{2}$ Congress enacted this "einergency legislation" in an effort "to stop the financial hemorrhaging." Unfortunately for some, Congress was both in a hurry ${ }^{5}$ and in a very bad mood. ${ }^{6}$ The result was a punitive piece of legislation that has fallen harshly on an often forgotten group of actors in the S\&L drama, the nondepositor creditors of insolvent financial institutions. These actors include, among others, the thrifts' enployees, trade creditors, landlords, and security holders.

Congress was not venturing into completely unchartered territory in sorting out the rights of bank and thrift creditors to the assets of failed institutions. The Bankruptcy $\mathrm{Code}^{7}$ (the Code)

1. Pub. L. No. 101-73, 103 Stat. 183 (codified in scattered sections of 12 U.S.C. and 18 U.S.C.).

2. Lawrence J. White, The S\&L Debacle: Public Policy Lessons for Bank AND THRIFT REGULATION 175 (1991).

3. Resolution Trust Corp. v. Diamond, 18 F.3d 111, 113 (2d Cir. 1994) (quoting S. REP. No. 19, 101st Cong., 1st Sess. 3 (1989)), cert. denied, 1155 S. Ct. 2609 (1995).

4. Id.

5. See WHITE, supra note 2, at 176 (noting that losses from insolvent thrifts continued to mount in the five months it took Congress to enact FIRREA).

6. See id. at 180-81. White states:

In an important sense, the FIRREA was an Act of anger. The Congress... [was] angry over the necessity to spend large sums to clean up the problems of the insolvent thrifts. ... The Congress believed it was "bailing out the thrifts," rather than being asked to satisfy its obligations on an insurance arrangement .... This auger ... manifested itself in a number of the provisions of the FIRREA, with deleterious consequences for all concerned.

Id.

7. 11 U.S.C. $\S \S 1-1330$ (1994). 
provides a complex framework for resolving the analogous question of who is entitled to what when an imdividual or corporation becomes insolvent. In fact, it has been said that FIRREA created a "parallel regime" for financial institutions. ${ }^{8}$ While it is true that FIRREA does resemble the Code, it differs sharply froin the Code in at least one important respect. Whereas the Code aspires to change the relative rights existing at the date of bankruptcy as little as possible, ${ }^{9}$ FIRREA can make no such claim. FIRREA severely curtails the rights of parties who were unlucky enough to enter into agreements with financial institutions.

The rights of nondepositor creditors are primarily affected by the jomt action of two related provisions of FIRREA. The first is the extraordinary power of the Federal Deposit Insurance Corporation (FDIC) and the Resolution Trust Corporation (RTC) (collectively "the agencies") when acting as receivers and conservators for failed banks and thrifts ${ }^{10}$ to repudiate any contract to which an insolvent institution is a party. ${ }^{11}$ This power may not seem extraordinary given that contracting parties generally have the option of breaching their agreements and answering in damages. What makes this ability extraordinary is that FIRREA also limits the damages for which the agencies inust answer to "actual direct compensatory damages." 12 The agencies' repudiation powers, combined with FIRREA's hinitation on damages, give thein the ability to breach contracts with virtual impunity in some cases. ${ }^{13}$

Part I of this Note examines the ability of the agencies to repudiate contracts and FIRREA's damage provisions. Part II compares the remedies available to creditors under FIRREA with those available under both traditional contract law and the Bankruptcy Code, illustrating the extent to which FIRREA has curtailed creditors' claims. Part III argues that FIRREA's drastic departure from both contract and bankruptcy laws was an unjust atteinpt by Congress to reduce the government's own losses as

8. Unisys Fin. Corp. v. Resolution Trust Corp., 979 F.2d 609, 611 (7th Cir. 1992).

9. See infra note 45 and accompanying text.

10. The powers of the FDIC and the RTC in their capacities as receivers and conservators are discussed in detail infra notes $21-26$ and accompanying text.

11. 12 U.S.C. $\S 1821$ (e) (1994); see infra notes $27-29$ and accompanying text.

12. 12 U.S.C. § 1821(e)(3); see infra notes 30-36 and accompanying text.

13. See, e.g., Howell v. FDIC, 986 F.2d 569 (1st Cir. 1993) (denying recovery under repudiated severance agreenent); Unisys Fin. Corp. v. Resolution Trust Corp., 979 F.2d 609 (7th Cir. 1992) (denying recovery under repudiated lease agreement). 
insurer of deposit liabilities at the expense of bank and thrift creditors. ${ }^{14}$ Part III also asserts that the limitation of creditors' claims is no longer necessary in light of the implementation in 1993 of a national depositor preference in receivership proceedings. Depositor preference ensures that the FDIC as subrogee of depositors' claims will recover in full before contract creditors receive a dime. ${ }^{15}$ Finally, Part IV concludes that FIRREA's damage limitations have created uncertainty and increased the cost to creditors of contracting with financial institutions. These increased costs are then passed on to banks and thrifts. FIRREA's damage limitations are therefore not only inequitable and unnecessary, but also costly and should be repealed.

\section{THE POWER OF THE RTC AND FDIC TO REPUdiATE CONTRACTS WITH VIRTUAL IMPUNITY}

FIRREA created the RTC to carry out the task of managing and disposing of the assets of insolvent savings and loan associations. ${ }^{16}$ In order to fulfill its mission, the RTC was given the authority to act as conservator or receiver for msured savings associations. ${ }^{17}$ The FDIC possesses comparable authority with respect to insured banks. ${ }^{18}$ Congress's aim in appointing the FDIC or RTC as conservator or receiver is to prevent the further deterioration in value of a bank's or thrift's assets. ${ }^{19}$ Any delay

14. See infra notes $145-49$ and accompanying text.

15. See infra notes $150-57$ and accompanying text.

16. See 12 U.S.C. § 1441a(b) (1994).

17. Id. $\S 1441 \mathrm{a}(\mathrm{b})(4)(\mathrm{A})$. Prior to the enactment of FIRREA, the Federal Savings and Loan Insurance Corporation (FSLIC) acted as receiver for all closed savings associations. Federal Regulation of DepostTory Institutions: ENFORCEMENT POWERS AND PROCEDURes II 9.01 (Miles A. Cobb ed., cum. supp. 1991) [hereinafter POWERS AND Procedures]. The FSLIC was abolished by FIRREA. Pub. L. No. 101-73, § 401, 103 Stat. 183, 354-63 (1989).

18. The authority of the FDIC to act as conservator or receiver is found in the Federal Deposit Insurance Act, 12 U.S.C. $\$ 1821$ (c) (1994). The RTC is a temporary agency that will cease to exist as an entity as of December 31,1995, at which time the FDIC will take over as conservator or receiver of failed savings associations. 12 U.S.C. $\S 1441 \mathrm{a}(\mathrm{In})(1)$ (1994). As of March 14, 1995, the RTC had sold the last group of insolvent $S \& L$ associations under its control, signalling an end to the agency's role in the S\&L crisis. Jack Mazzeo, Thrift Agency Sells Last Group of S\&Ls Under Its Control, WALL ST. J., Mar. 14, 1995, at B12.

19. See WHITE, supra note 2, at 232-33. 
in appointing a conservator or receiver increases the ultimate cost to the FDIC as the insurer of deposits. ${ }^{20}$

The FDIC or RTC is appointed conservator or receiver in the event that a depository institution is insolvent," is in an "unsafe or unsound condition to transact business," or "is likely to be unable to pay its obligations or meet its depositors' demands in the normal course of business."22 When a receiver is appointed, the institution's owners lose control of the institution's assets and their ownership interest in the institution is completely extinguished..$^{23}$ The appointment of a conservator is a less drastic measure, which, while reinoving control of the assets froin the owners, allows them to retain a claim against the assets that are being "conserved." 24 As conservators and receivers, the agencies have the authority to "take over the assets of, operate, and conduct the business of institutions for which they are appointed, and hold all powers of the inembers or shareholders, directors, and officers of such institutions."25 As receivers, the FDIC and RTC may also liquidate the assets of insolvent institutions. ${ }^{26}$

In addition to entrusting the FDIC and RTC with all of the powers that the directors, officers, and shareholders once held, FIRREA provides the agencies with certain extraordinary powers, including the broad authority to repudiate any contract to which the bank or thrift is a party. ${ }^{27}$ The FDIC need only determine in its discretion that the contract is "burdensome" and that repudiation would "promote the orderly administration of the institution's affairs." ${ }^{28}$ This power is virtually limitless and is subject only to

20. Id.

21. A depository institution is insolvent when "[t]he institution's assets are less than the institution's obligations to its creditors and others, including members of the institution." 12 U.S.C. $\$ 1821$ (c)(5)(A) (1994).

22. Id. § 1821(c)(5)(C), (F).

23. WHITE, supra note 2 , at 232.

24. Id. at 234 .

25. Powers AND Procedures, supra note 17, II 9.02[3][a]; see 12 U.S.C. $\S 1821(\mathrm{~d})(2)(\mathrm{B})(\mathrm{i})(1994)$.

26. 12 U.S.C. $\S 1821(\mathrm{~d})(2)(\mathrm{E})$.

27. See id. $\S 1821(\mathrm{e})(1)(\mathrm{A})$.

28. Id. § 1821(e)(1)(B)-(C); see Hennessy v. FDIC, 58 F.3d 908, 920 (3d Cir. 1995) (noting that "there is no requirement that the conservator or receiver make a formal finding that a lease or contract is burdensome" and that "whether the lease is burdensome is to be decided at the discretion of the conservator or receiver" (quoting 1185 Avenue of the Anericas Assocs. v. Resolution Trust Corp., 22 F.3d 494, 498 (2d Cir. 1994)); Arthur Leibold, Jr., S\&L Regulators Throw Weight Around, TEXAS LAWYER, July 
the minor restriction that repudiation take place within a "reasonable period" following the appointment of a conservator or receiver. ${ }^{29}$

This ability to abrogate contracts takes on special significance when combined with FIRREA's limitation on the claims resulting froin the repudiation of these contracts. FIRREA limits the agencies' liability to "actual direct compensatory damages" as of the date of repudiation. "Actual direct compensatory damages" specifically do not imclude "punitive or exemplary damages," "dainages for lost profits or opporturity," or "damages for pain and suffering." 31 With respect to repudiated leases, FIRREA specifically limits recovery to the amount of rent accrued as of the date of repudiation and provides that no recovery will be had under any acceleration clause or penalty provision. ${ }^{32}$

FIRREA, however, is noticeably silent on what is included in "actual direct compensatory damages." 33 The legislative history surrounding the passage of FIRREA also sheds no light on Congress's purposes or intent in crafting this provision. ${ }^{34}$ The D.C. Circuit ventured a guess at Congress's intent in drafting this restrictive damage provision, stating that "Congress appears to us to have wished to distinguish between those damages which can be

30, 1990, at 22 ("The possible breadth of this discretion is startling. Most non-executory contracts cau be called 'burdensoune' if the only remaining act is to pay the person who has furnished consideration. It is burdensome, after all, to pay bills.").

29. 12 U.S.C. \& 1821(e)(2) (1994). Courts have not determined definitively what constitutes a "reasonable period" of time. See, e.g., Resolution Trust Corp. v. Cedarminn Bldg. L.P., 956 F.2d 1446, 1455 (8th Cir.) (stating that "Congress specifically intended to give RTC flexibility in determining what constitutes a reasonable period for repudiation"), cert. denied, 113 S. Ct. 94 (1992); Monument Square Assocs. v. Resolution Trust Corp., 792 F. Supp. 874, 878 (D. Mass. 1991) (stating that reasonable period determined by looking at "circumstances of each case"); 701 NPB Assoc. v. FDIC, 779 F. Supp. 1336, 1339 (S.D. Fla. 1991) (finding reasonable period to be "fact sensitive"); Rechler Partnership v. Resolution Trust Corp., 1990 U.S. Dist. LEXIS 18714, at *25 (D.N.J. Sept. 4, 1990) (stating that reasonable is "fact sensitive time").

30. 12 U.S.C. $\$ 1821(\mathrm{e})(3)(\mathrm{A})(\mathrm{i})$-(ii) (1994).

31. Id. \& $1821(\mathrm{e})(3)(\mathrm{B})(\mathrm{i})$-(iii).

32. Id. \& $1821(\mathrm{e})(4)(\mathrm{B})(\mathrm{i})-(\mathrm{ii})$.

33. According to Corpus Juris Secundum, “'Compensatory daunages' and 'actual damages' are synonymous terms ... and include[] all damages other than punitive or exemplary damages." 25 C.J.S. Damages $\$ 2$ (1966). This definition is unenlightening because the statute specifically excludes both pumitive and exemplary damages. 12 U.S.C. § $1821(\mathrm{e})(3)(\mathrm{B})(\mathrm{i})$.

34. See Howell v. FDIC, 986 F.2d 569, 572 (1st Cir. 1993) ("If there is any illuminating legislative history or precedent, it has not been called to our attention by the parties and we have been unable to locate anything very helpful."). 
thought to make one whole and those that are designed to go somewhat further and put a plaintiff securely in a financial position he or she would have occupied but for the breach."35 The First Circuit was less kind in its assessment, suggesting instead that the phrase "actual direct compensatory damages" was "plucked out of the air by Congress." 36 It appears that any further insight into the meaning of "actual direct compensatory damages" will have to be gleaned from the decisions of the courts that continue to apply this provision.

\section{A COMPARISON OF THE REMEDIES}

AVAILABLE UNDER FIRREA, TRADITIONAL

CONTRACT LAW, AND THE BANKRUPTCY CODE

The degree to which Congress has pared back claims for dainages can be illustrated by comparing the recoveries of nondepositor creditors under FIRREA with the remedies that would otherwise be available to the same creditors (1) had the financial institutions with whoin they dealt breached their agreements prior to entering conservatorship or receivership, or (2) had the creditors dealt with insolvent parties other than financial institutions. These comparisons reveal that FIRREA represents a significant departure from both traditional contract law and bankruptcy law that is extremely unfavorable for contract creditors of insolvent financial institutions.

If a bank or thrift were to breach a contract prior to entering conservatorship or receivership, that institution, like any other party to a contract, would be subject to a claim for damages by the imjured party. According to the Restatement Second of Contracts,

Ordinarily, when a court concludes that there has been a breach of contract, it enforces the broken promise by protecting the expectation that the injured party had when he made the contract. It does this by attempting to put him in as good a position as he would have been in had the contract been performed, that is, had there been no breach. The interest protected in this way is called the "expectation interest." It is sometimes said to give the injured party the "benefit of the bargain." 37

35. Office and Professional Employees Int'l Union, Local 2 v. FDIC, 27 F.3d 598, 604 (D.C. Cir. 1994).

36. Howell, 986 F.2d at 572.

37. RESTATEMENT (SECOND) OF CONTRACTS $\S 344 \mathrm{cmt}$. a (1981); see also CORBIN 
In protecting a party's "expectation interest," courts may choose from a wide range of permissible remedies, including awarding "Inoney due under the contract or as damages" or "requiring specific performance of a contract or enjoining its non-performance. ${ }^{38}$ A contract may also stipulate in advance what damages will be payable in the event of breach. ${ }^{39}$

In contrast, FIRREA specifically disallows claims for lost profits and opportunities, ${ }^{40}$ which. are commonly awarded by courts to protect parties' expectation interests. In order to recover under FIRREA, a creditor inust also demonstrate that the damages sought are "actual." of hquidated dainages. ${ }^{42}$ In addition, FIRREA specifically denies lessors the benefit of their bargains by disallowing all claims other than those for back rent. ${ }^{43}$

Likewise, it appears that nondepositor creditors of financial institutions fare worse than creditors who have dealt with insolvent parties other than financial institutions. Because both bankruptcy law and FIRREA deal with the distribution of assets in the context of nisolvency, it would be logical to assume that creditors would receive similar protections under these "parallel regime[s]." ${ }^{44}$ However, a coinparison of the basic principles underlying these two bodies of law provides the first clue that this assumption is mcorrect. Underlying bankruptcy law is the general principle that, in determining which creditors will receive which assets in bankruptcy, the starting point is nonbankruptcy law: "Bankruptcy law aspires to change rights only as much as is necessary in

ON CONTRACTS Damages § 992 (1964).

38. RESTATEMENT (SECOND) OF CONTRACTS $\S 345(a)$-(b).

39. Id. § 356(1). Liquidated damages must be "reasonable in the light of the anticipated or actual loss. . . A term fixing unreasonably large liquidated damages is unenforceable on grounds of public policy as a penalty." Id.

40. 12 U.S.C. \& 1821(e)(3)(B)(ii) (1994).

41. Id. \& 1821(e)(3)(A)(i).

42. See, e.g., Howell v. FDIC, 986 F.2d 569, 573 (1st Cir. 1993) ("Severance payments, stipulated in advance, are at best an estimate of likely harm . . . Such payments comprise or are analogous to 'liquidated damages' ....").

43. 12 U.S.C. \& 1821(e)(4).

44. Unisys Fin. Corp. v. Resolution Trust Corp., 979 F.2d 609, 611 (7th Cir. 1992). Courts have referred to bankruptcy by analogy when interpreting FIRREA. See, e.g., Citibank (South Dakota), N.A. v. FDIC, 827 F. Supp. 789, 793 (D.D.C. 1993) ("[T]lie Court finds provisions of bankruptcy law instructive."), mot. for recons. granted in part and denied in part, 857 F. Supp. 976 (D.D.C. 1994). 
order to vindicate bankruptcy policy." ${ }^{25}$ No such principle underlies FIRREA. FIRREA purposely seeks to limit the claims that would otlerwise be available to nondepositor creditors in the absence of FIRREA. ${ }^{46}$

While both the Bankruptcy Code and FIRREA treat rejection or repudiation as breaches of contracts that give rise to claims for damages, ${ }^{47}$ these "parallel regime[s]" ${ }^{38}$ differ in their treatınent of the claims that arise. In bankruptcy, the ineasure of damages is generally determined by reference to applicable nonbankruptcy law with the exception of special provisions for clains brought by employees and landlords of debtors. ${ }^{49}$ In contrast, claims against the FDIC and RTC are generally limited to "actual direct coinpensatory damages" witl the exception of an even more restrictive provision dealing witl claims arising froin the repudiation of leases..$^{50}$

45. Douglas G. BAird, THE Elements of Bankruptcy 83 (rev. ed. 1993). The Supreme Court has stated: "Property interests are created and defined by state law. Unless some federal interest requires a different result, there is no reason why such interests should be analyzed differently simply because an interested party is involved in a bankruptcy proceeding." Butner v. United States, 440 U.S. 48, 55 (1979).

46. See Peter P. Swire, Bank Insolvency Law Now That It Matters Again, 42 DUKE L.J. 469, 477-90 (1992) (noting many ways in which bank insolvency law differs from bankruptcy law).

47. See 11 U.S.C. $\& 365(\mathrm{~g})$ (1994) ("[R]ejection of an executory contract or unexpired lease of the debtor constitutes a breach of such contract or lease."); Howell v. FDIC, 986 F.2d 569, 571 (1st Cir. 1993) (stating that repudiation is treated as breach giving rise to claim for damages).

48. Unisys Fin. Corp., 979 F.2d at 611.

49. GEORge M. TREISTER ET AL., Fundamentals of BanKRuptCY LAW 271 (3d ed. 1993). Provisious concerning leases and employees are located at 11 U.S.C. $\S 502(\mathrm{~b})(6),(7)$.

50. See 12 U.S.C. § 1821(e) (1994). The Code also differs from FIRREA in that it does not grant the bankruptcy trustee the sweeping authority to repudiate any contract that the trustee finds to be "burdensome." The Code grants a trustee only the limited power to "reject" executory contracts and unexpired leases. See 11 U.S.C. \& 365(a). An executory contract is one "under which the obligation of both the bankrupt and the other party to the contract are so far unperformed that the failure of either to complete performance would constitute a material breach excusing the performance of the other." Vern Countryman, Executory Contracts in Bankruptcy, 57 MiNN. L. Rev. 439, 460 (1973). In contrast, the FDIC and the RTC have the authority under FIRREA to repudiate any contract, leading soine commentators to suggest that the agencies may repudiate agreements even when the only performance remaining is the payment of money. See Leibold, supra note 28, at 22; POWERS AND PROCEDURES, supra note 17, II 9.02[6][a] ("The question is whether the FDIC and the RTC can repudiate a contract that has been fully performed. The legislative history of FIRREA is silent on the question, but the statutory language inakes a strong case for repndiation of contracts that have been fully performed as well as executory contracts."); see also Hennessy v. FDIC, 58 F.3d 908, 919 n.8 (3d Cir. 1995) (dictum) ("As many courts have noted, the statute explicitly provides that a conser- 
The following cases illustrate the courts' application of FIRREA's damage provisions to claims arising froin three types of contracts: severance agreements, leases, and non-compete agreements. While failing to provide a clear definition of "actual direct compensatory damages," the cases do reveal that FIRREA's damage provisions are an abrogation of both contract and bankruptcy law. The cases also provide soine clues regarding the extent to which contract creditors of failed banks and thrifts can expect to recover.

\section{A. Recovery Under Severance Agreements}

"A stranger to FIRREA might think it apparent that breach of a contract to make severance payments inflicts damages on a discharged employee in the amount of the promised payments." 51 Unfortunately, an analysis of recent decisions leads to the conclusion that recovery for discharged einployees is far from certain. At present, the courts of appeals are spht on the issue of whether repudiation by the FDIC or RTC of a severance agreement entered into between a depository institution and its employees gives rise to a clain for "actual direct compensatory damages."

While acknowledging that its result "[was] a severe one," the First Circuit held in Howell v. FDIC that the officers of Eliot Savings Bank could not recover under their severance agreements with the failed bank. ${ }^{53}$ The First Circuit viewed the severance payments as "liquidated damages" that are, by definition, not "actual damages." The court acknowledged that severance pay-

vator or receiver 'may disaffirm any contract or lease,' not just executory contracts [emphasis omitted]."). But see Marsa v. Metrobank for Savings, F.S.B., 825 F. Supp. 658, 665-66 (D.N.J. 1993) (dictum) (concluding that receiver precluded from repudiating nonexecutory contracts), aff'd, 26 F.3d 122 (3d Cir. 1994).

51. Howell v. FDIC, 986 F.2d 569, 572 (1st Cir. 1993).

52. Compare Howell, 986 F.2d at 569 (disallowing employees' claims for severance benefits under repudiated severance agreements) and Hennessy, 58 F.3d at 908 (same) with Office and Professional Einployees Int'l Union, Local 2 v. FDIC, 27 F.3d 598 (D.C. Cir. 1994) (allowing employees to recover severance payments under repudiated collective bargaining agreement) and Monrad v. FDIC, 62 F.3d 1169 (9th Cir. 1995) (allowing employees to recover severance payments under repndiated severance agreement).

53. Howell, 986 F.2d at 570. The bank had agreed to pay the four officers an amount that represented between one and three years of their salaries "in consideration of the officers' 'willingness to remain' in the bank's employ" despite the bank's unstable financial condition. Id.

54. Id. at 573; see also Hennessy, 58 F.3d at 921 ("We share the view of the Court of Appeals for the First Circuit that these payments are analogous to 'liquidated damag- 
ments are often a "good-faith effort" to estimate actual damages arising from the termination of one's employment, but found that the "spirit" of the statute does not permit such a construction given Congress's intention to "strictly ... limit allowable claims for repudiated contracts." 55

In Hennessy v. FDIC, ${ }^{56}$ the Third Circuit adopted the First Circuit's reasoning in Howell, holding that severance payments are analogous to hquidated damages and therefore not compensable under FIRREA. ${ }^{57}$ In addition, the Third Circuit's opinion illustrates yet another approach used by some courts in disallowing claims for severance benefits. The FDIC argued that, before determining whether FIRREA disallows severance payments as an impermissible form of damages, the court must first determine whether the plaintiffs have a vahid claim for severance pay. ${ }^{58}$

es.' "); Resolution Trust Corp. v. Management, Inc., 25 F.3d 627, 632 (8th Cir. 1994) (citing Howell and stating that clause requiring payment due upon termination of management company's contract "could be characterized as a liquidated damage clause" and that "[n]either severance fees nor future lost profits are compensable under FIRREA"); Westport Bank \& Trust Co. v. Geraghty, 865 F. Supp. 83, 86 (D. Conn. 1994) (dictum) (citing Howell and stating that damages resulting from the repudiation of a severance package are not "actual direct compeusatory damages" because they are analogous to liquidated damages). Cf. Fresca v. FDIC, 818 F. Supp. 664 (S.D.N.Y. 1993) (citing Howell as authority but finding that medical and life insurance benefits sought by plaintiffs were not aualogous to liquidated damages).

55. Howell, 986 F.2d at 573. The officers also argued that the FDIC, prior to becoming receiver, had encouraged the bank to "take steps to retain its qualified management" and alleged that the FDIC "knew and approved" of their severance agreements. Id. at 571. The officers argued that, because the FDIC had a hand in forming the severance agreemeuts, it was estopped from repudiating the agreemeuts. Id. at 574. The court rejected these arguments, invoking the "separate capacities" doctrine which treats the FDIC as "two separate persons" when acting as regulator prior to receivership and when acting as a receiver. Id.; see also Westport Bank \& Trust Co., 865 F. Supp. at 83 (holding that the FDIC was not estopped from repudiating severance agreement as receiver despite having consented to the agreement while acting as regulator). The Howell court also rejected the officers" argumeut that the application of the "separate-capacities" doctrine would produce unjust results, stating that the injustice would be no "greater than occurs in the usual case in which the separate-capacities doctrine is invoked." Howell, 986 F.2d at 574. The "separate capacities" doctrine has also been used to permit the FDIC and the RTC, when acting as receivers, to repudiate agreements that they had previously accepted in their roles as conservators. See, e.g., 1185 Ave. of the Americas Assocs. v. Resolution Trust Corp., 22 F.3d 494, 498 (2d Cir. 1994); Resolution Trust Corp. v. Cedarminn Bldg. L.P., 956 F.2d 1446, 1450 (8th Cir.), cert. denied 113 S. Ct. 94 (1992); Monument Square Assocs. v. Resolutiou Trust Corp., 792 F. Supp. 874, 878 (D. Mass. 1991).

56. 58 F.3d 908 (3d Cir. 1995).

57. Id. at 921 .

58. Id. at $917-19$. 
The court stated that " $[t] 0$ establish a claim against an insolvent bank in receivership, the liability of the bank must have accrued and become unconditionally fixed on or before the time it is declared insolvent. ... If nothing is due at the time of insolvency, the claim slould not be allowed ...., that, because the terms of the plaintiffs' severance agreeinents provided that payments were triggered in the event of "lack of work, job elimination, reorganization, or reduction in work force" but not explicitly in the event of insolvency, the plaintiffs' rights to severance payments were "contingent at the time of the appointment of the receiver." 60 Because the plaintiffs were not terminated prior to the appointment of the receiver, they did not have a claim for damages. ${ }^{61}$

59. Id. at 918 (quoting Kennedy v. Boston-Continental Nat'l Bank, 84 F.2d 592, 597 (1st Cir. 1936)); see also Westport Bank \& Trust Co., 865 F. Supp. at 86 (dictum) ("As of the date of [the bank's] insolvency, the claimants' benefits under their employment agreements had not becoine vested in that the payment of the trust funds were contingent upon prior termination of their employment.").

60. Hennessy, 58 F.3d at $913,918$.

61. Courts have also disallowed claims for severance pay under 12 C.F.R. $\S 563.39$, which provides guidelines for federally insured savings associations (but not banks) to follow when entering into employment contracts with officers and employees. See, e.g., Modzelewski v. Resolution Trust Corp., 14 F.3d 1374, 1378-79 (9th Cir. 1994); Fleischer v. Resolution Trust Corp., 882 F. Supp. 1010, 1015 (D. Kan. 1995); Romines v. GreatWest Life Assur. Co., 865 F. Supp. 607, 610 (E.D. Mo. 1994); Rush v. FDIC, 747 F. Supp. 575, 578 (N.D. Cal. 1990). 12 C.F.R. $\$ 563.39$ (b)(4) (1995) provides: "If the savings association is in default, ... all obligations under the [employment] contract shall terninate as of the date of default, but this paragraph (b)(4) shall not affect any vested rights of the contracting parties ...." The Ninth Circuit has held that benefits are "vested when the employee holding the right is entitled to claim immediate payment." Modzelewski, $14 \mathrm{F.3d}$ at 1378 . Therefore, if "termination without cause is a condition precedent to the vesting of an employee's rights, no vesting occurs when his or her contract is extinguished by operation of law pursuant to $\S 563.39(b)[(4)]$ ]" Romines, 865 F. Supp. at 610 (citing Crocker v. Resolution Trust Corp., 747 F. Supp. 575, 578-79 (N.D. Cal. 1990)).

Although the Ninth Circuit has held that claims for severance benefits under agreements terminated pursuant to $\S 563.39$ are not vested, and therefore not compensable, unless an employee is terminated prior to the appointment of a receiver, it has taken a contrary position with respect to claims that arise from the repudiation of severance plans not subject to termination under $\S 563.39$. Compare Modzelewski, 14 F.3d at 1379-80 with Monrad v. FDIC, 62 F.3d 1169, 1173 (9th Cir. 1995). In Monrad, the Ninth Circuit stated, "[T]he fact that actual termination post-dates the appomtment of the receiver is insufficient to defeat an otherwise valid claim for severance pay." $62 \mathrm{~F} .3 \mathrm{~d}$ at 1174 . Although the Ninth Circuit did not attempt to reconcile these two opinions, it is possible to distinguish Modzelewski as an exercise of the Ninth Circuit's authority to iuterpret an nndefined term ("vested") in a federal statute. In contrast, the determination of whether rights are sufficiently vested or accrued in the absence of a statute is a question of con- 
This result is startling given that many troubled banks and thrifts offered their managers severance agreements as compensation for their continued employment at a time when the futures of the institutions employing them were highly uncertam. ${ }^{62}$ The purpose of the agreements was to protect against the possibility that the banks' financial conditions would deteriorate further and that management would be unemployed in the near future. Iromically, the event from which employees sought to protect theinselves-insolvency-was the event that made their severance agreements worthless.

In contrast, the D.C. Circuit has wisely rejected the arguments of the First and Third Circuits. In Office and Professional Employees International Union, Local 2 v. FDIC, ${ }^{63}$ the D.C. Circuit held that the employees of the National Bank of Washington were entitled to severance payinents under a collective bargaiming agreement that the FDIC as receiver repudiated. ${ }^{64}$ The court first rejected the argument that severance benefits are not recoverable unless the right to receive them has "vested" at the date of receivership. ${ }^{65}$ Judge Silberman persuasively argued,

tract law to be determined with reference to applicable state law. See Nashville Lodging Co. v. Resolution Trust Corp., 59 F.3d 236, $244-45$ (D.C. Cir. 1995) (applying Tennessee law in determining whether claim for damages under repudiated contract had "accrued"). Therefore, a claim that would be found to be unvested if judged under the stringent test fashioned by the Ninth Circuit for claims arising under $\S 563.39$ may nevertheless be sufficiently vested under applicable contract laws so as to be compensable.

62. See, e.g., Hennessy, 58 F.3d at 914 (Management received letters stating that the bank "is acntely aware that [it] is essential to retain motivated employees such as you in key positions. As evidence of this awareness, [the bankl is extending . . . the Separation Pay Program to a total of 52 weeks pay."); Howell v. FDIC, 986 F.2d 569, 570 (1st Cir. 1993) (noting that severance agreements were made "in consideration of the officers' 'willingness to remam' in the bank's employ" despite the bank's unstable financial condition).

63. 27 F.3d 598 (D.C. Cir. 1994).

64. Id. at 601. The Ninth Circuit has also rejected the reasoning of the First and Third Circuits, stating that Office and Professional Employees "offers the better-reasoned approach. FDIC's liability for 'actual direct compensatory damages' . . . includes severance pay." Monrad v. FDIC, 62 F.3d 1169, 1174 (9th Cir. 1995).

65. Office and Professional Employees, 27 F.3d at 601-02; see also Monrad, 62 F.3d at 1174; Soriero v. FDIC, 887 F. Supp. 103, 108 (E.D. Pa. 1995); Citibank (South Dakota), N.A. v. FDIC, 827 F. Supp. 789, 791 (D.D.C. 1993) (The court rejected the FDIC's argument that the plaintiff's claim should be disallowed because it was contingent: "[C]laims are always contingent on the date of insolvency because a receiver cannot repudiate a contract until after it is appointed."), mot. for recons. granted in part and denied in part, 857 F. Supp. 976 (D.D.C. 1994). Cf. Nashville Lodging Co., 59 F.3d at 244 ("The idea that an obhigation must have become absolute by the time of insolvency had clearly weakened even before FIRREA's adoption, however, and it plainly has not 
The employees had the right to severance pay as of the date of appoimtment-albeit a contingent one ... . That severance payments are not paid unless and until an employee is terminated (laid off) for economic reasons, while significant for determining the value of the payments at any given time, does not mean that the right to such severance is worthless until the date of termination. ${ }^{66}$

This court, unlike the Third Circuit, recognized that the severance agreements were meant to be part of the "employee's compensation package." 67 Judge Silberman stated that "it can hardly be suggested that this sort of protection lacks any immediate value-particularly after the last few years of 'downsizing' in the American labor market." 68

The court found that the closest analogy to severance payments is a bank's issuance of a standby letter of credit requiring the bank to pay the holder in the event that a third party defaults. ${ }^{69}$ Such claims are valid "even though the bank's obligation to pay is still contingent as of the date of insolvency."70 Judge Silberman saw "no reason why the result should be different for severance payments where the termination is not effected until after the appoimtment of the receiver."71

The court also disagreed with the First Circuit's labeling in Howell of severance payments as "liquidated ... damages." "T2 The D.C. Circuit stated that the First Circuit "overlooked, in our opinion, the point that an employer's promise to make severance pay-

survived the statute's specification of claims recoverable upon repudiation in 12 U.S.C. $\S 1821(\mathrm{e})(3) . ")$.

66. Office and Professional Employees, 27 F.3d at 601.

67. Id.

68. Id. at 602; see also LaMagna v. FDIC, 828 F. Supp. 1, 2-3 (D.D.C. 1993) ("To have any meaning, a promise for severance benefits must vest at the moment the parties finalize their agreement. The very purpose of the severance provision was to protect LaMagna from the type of events which transpired ....").

69. Office and Professional Employees, 27 F.3d at 602.

70. Id.

71. Id. at 603. The D.C. Circuit held that the FDIC's reliance on certain ERISA cases, which held that severance benefits are not "vested," was misplaced. Id. at 602 . The court stated that those cases do not address "whether a promise to make severance payments may be binding and enforceable under contract law." Id.

72. Id. at 603. See supra notes 53-55 and accompanying text for a description of the First Circuit's arguments in Howell v. FDIC, 986 F.2d 569 (1st Cir. 1993). 
ments is part of the consideration of the employment contract."73 Judge Silberman also pointed out that the employees in Howell had an "at will" relationship with the bank. ${ }^{74}$ Because the bank was free to termmate the employees "at will" without subjecting itself to a claim for damages, the severance payments could not have been intended as "liquidated damages."

Congress's enactment in 1990 of specific provisions disallowing "golden parachute" payments ${ }^{76}$ provides further support for the D.C. Circuit's holding that FIRREA does not mandate the disallowance of claims for severance pay. "As David R. Levinson, the attorney for the plaintiffs in Office and Professional Employees, ${ }^{78}$ argued, "[I]f [FIRREA] really excluded severance pay ... Congress was wasting its time in enacting ... the golden parachute provision." ${ }^{79}$ The First and Third Circuits' holdings also appear contrary to the regulations proposed by the FDIC to implement the "golden parachute" provisions ${ }^{80}$ that specifically permit the FDIC to make payments to employees under "nondiscrimmatory severance pay plan[s]"81 and to individuals hired for the specific purpose of "saving" institutions. ${ }^{82}$ The FDIC, however, has under-

73. Office and Professional Employees, 27 F.3d at 603.

74. Id.

75. Id.

76. See 12 U.S.C. $\S 1828(k)$ (1994). Section $1828(k)(4)(A)$ defines a "golden parachute payment" as

any payment (or any agreemeut to make any payment) in the nature of coinpensation by any insured depository institution ... for the benefit of any institution-affiliated party pursuant to an obligation of such institution . . . that-(i) is contingent on the termination of such party's affiliation with the institution ...; and (ii) is received on or after the date on which-(I) the insured depository institution .... is insolvent; (II) any couservator or receiver is appointed for such institution; [or] (III) the mstitution's appropriate Federal banking ageucy determines that the insured depository institution is in a troubled condition ....

A payment is also a "golden parachute payment" if the payment was made in contemplation of any of the events histed in $\S 1828(\mathrm{k})(4)$. Id. $\S 1828(\mathrm{k})(4)(\mathrm{B})$.

77. Id. § 1828( $\mathrm{k})$.

78. 27 F.3d 598 (D.C. Cir. 1994).

79. See Severance Pay Sanctioned; Panel Limits FDIC Power to Reject Union Pacts, THE BANKNG ATTORNEY, July 25, 1994, at 1, 2.

80. 60 Fed. Reg. 16,069 (1995) (to be codified at 12 C.F.R. § 359). The FDIC proposed a previous set of regulations implementing $\S 1828(\mathrm{k})$ in 1991. See 56 Fed. Reg. 50,529 (1991). The FDIC decided to issue a second set of regulatious to address the comments received during the public comment period. See 60 Fed. Reg. 16,069, 16,069 (1995).

81. See 60 Fed. Reg. 16,069, 16,079 (to be codified at 12 C.F.R. § 359.1(f)(2)(v)).

82. See id. at 16,081 (to be codified at 12 C.F.R. $\S 359.4(a)(2)$ ). 
standably chosen not to view the favorable court decisions such as those in Howell ${ }^{83}$ and Hennessy ${ }^{84}$ as contrary to its regulations. A footnote to the supplementary information preceding the proposed regulations states that "[c]laims for certain benefits may not be provable or constitute 'actual direct compensatory damages' . . . if the institution is placed in receivership. This regulation does not provide otherwise." ${ }^{85}$ Nevertheless, the FDIC's interpretation is tenuous given that the "golden parachute" provisions provide strong support for the view that Congress, when it passed the "golden parachute" provisions in 1990, did not believe that FIRREA had limited claims for severance pay.

Little can be said in conclusion about the recovery available under repudiated severance agreements other than that recovery is very uncertain. With five courts of appeals liaving addressed the issue, a consensus has yet to be reached as to whether claims under repudiated severance agreements constitute "actual direct compensatory damages." This lack of uniformity is not surprising given the inherent ambiguity of the phrase "actual direct compensatory damages. ${ }^{386}$ While the D.C. Circuit's arguments in favor of allowing claims for severance pay are both persuasive and more easily reconciled with Congress's specific disallowance of only certain types of severance agreements, the D.C. Circuit, joined by the Ninth Circuit, is currently in the minority on this issue. In the absence of clear guidelines, three circuits ${ }^{87}$ and several district courts $^{88}$ liave chosen to give effect to what can be viewed as a general intention by Congress to limit creditors' claims. Unfortunately for the einployees of failed banks and thrifts, Congress did not make clear exactly how far it intended to go in parmg back creditors' claims. ${ }^{89}$

83. 986 F.2d 569 (1st Cir. 1993).

84. 58 F.3d 908 (3d Cir. 1995).

85. 60 Fed. Reg. 16,069, 16,077 n.13 (1995).

86. See discussion supra notes 33-36 and accompanying text.

87. See Hennessy v. FDIC, 58 F.3d 908 (3d Cir. 1995); Howell v. FDIC, 986 F.2d 569 (1st Cir. 1993); see also Resolution Trust Corp. v. Management, Inc., 25 F.3d 627 (8th Cir. 1994) (deciding analogous issue of whether a severance fee owed to a management firm is compensable under FIRREA).

88. See, e.g., Westport Bank \& Trust Co. v. Geraghty, 865 F. Supp. 83 (D. Conn. 1994); Fresca v. FDIC, 818 F. Supp. 664 (S.D.N.Y. 1993) (dictum); Rush v. FDIC, 747 F. Supp. 575 (N.D. Cal. 1990).

89. The Third Circuit recognized this ambiguity:

[W] must contend with competing policy considerations. On the one hand, we have the concern raised in Howell that in drafting FIRREA, "Congress, faced 
The First and Third Circuits' total disallowance of severance payments appears especially harsh in comparison to the remedies that would otherwise be available to the discharged employees under either contract or bankruptcy law. If a bank were to breach a severance agreement with its employees prior to entering conservatorship or receivership, the employees would clearly be entitled to the amounts owed thein under the contract. Even in bankruptcy proceedings, employees have a claim for the amount to which they were entitled under their employment contracts for a period of one year..$^{90}$

This one-year limitation under bankruptcy law is justified as a means of curbing abuse by "insiders" to the "golden parachute" provisions applicable to insured financial institutions. The need to protect creditors in bankruptcy from certain transactions that are highly susceptible to abuse by "insiders"

with mountainous bank failures," was "determined to pare back damage claims founded on repudiated contracts ...." On the other hand, we must address the point raised in [Office and Professional Employees] that the question is not whether Congress meant to scale back damage claims, but "which damage claims, however few, are preserved."

Hennessy, 58 F.3d at 921.

90. 11 U.S.C. $\S 502(b)(7)$ (1994). In addition, the first $\$ 4,000$ of an employee's claim for any wages and severance benefits earned within the 90 days prior to the filing of the bankruptcy petition enjoy a priority over virtually all other claims. Id. $\S 507(\mathrm{a})$.

The treatment of collective bargaining agreements under bankruptcy law is somewhat more complicated. "Rejecting a collective bargaining agreement in bankruptcy has the effect of forcing the union to negotiate a new deal." BAIRD, supra note 45 , at 127. Procedures for bargaining are provided for in section 1113 of the Bankruptcy Code. Id. at 130 . This is the proper treatment because, outside of bankruptcy, a firm cannot escape its collective bargaining agreements. Id. It must "go back to the union and cut a new deal." Id. Similar treatment inside and outside of bankruptcy is needed to prevent parties from filing for bankrnptcy in order to avoid their collective bargaining agreements. See id. Section 1114 of the Code "requires the firm to keep paying retirees their medical benefits in the absence of renegotiations, and treats these obligations as administrative expenses." Id. at 129. However, "[o]bligations under a collective bargaining agreement disappear when a firm liquidates." Id. at 128. According to Baird, "To solve the problem that retirees face when their firms fail, one cannot rely completely on bankruptcy law. One must make sure that there are sufficient assets to cover the obligations and that firms are forced to meet these obligations whether they are in bankruptcy or not." $1 d$.

91. BAIRD, supra note 45 , at 94 . Baird explains:

Those employees most likely to be affected by the breacl of long-term employment contracts are einployees with golden parachutes and they frequently are insider-shareholders. When these contracts are unusually favorable, there may be a significant clrance of self-dealing that violates the rights of creditors as a group. The cap ... may be a means of policing misbehavior that is hard to identify.

Id. 
explains why the Bankruptcy Code provides for a more limited reinedy in this context than does traditional contract law. ${ }^{92}$ However, a similar explanation does not exist to justify the disparity between the Code's allowance of up to one year's severance pay and the view of the majority of courts that FIRREA totally disallows virtually all severance benefits. Not only does FIRREA deny employees the financial protections for which they have bargained, but it does so to an extent that is inconsistent with contract and bankruptcy laws.

\section{B. Recovery Under Lease Agreements}

Unlike claims under severance agreements, claims resulting froin the repudiation of lease agreeinents are not subject to FIRREA's ambiguous "actual direct compensatory dannages" limitation. FIRREA contains relatively straightforward provisions dealing specifically with damages arising from the repudiation of leases. ${ }^{93}$ The statute provides that recovery is limited to the annount of rent accrued as of the date of repudiation and that no recovery will be had under any acceleration clause or penalty provision. ${ }^{94}$ Unfortunately for those who leased property to financial institutions, Congress made perfectly clear that lessors are entitled to absolutely nothing in inost cases. ${ }^{95}$

The Seventh Circuit's opinion in Unisys Finance Corporation v. Resolution Trust Corp. ${ }^{96}$ is illustrative of the inanner in which courts have apphed FIRREA's lease repudiation provisions. ${ }^{97}$

92. See id.

93. See 12 U.S.C. § 1821(e)(4) (1994) ("(A) If the conservator or receiver disaffirms or repudiates a lease under which the insured depository institution was the lessee, the conservator or receiver shall not be liable for any damages ... for the disaffirmance or repudiation of such lease. (B) Notwithstanding subparagraph (A), the lessor . . . shall (i) be entitled to the contractual rent accruing ... (ii) have no claim for damages under any acceleration clause or other penalty provision in the lease; and (iii) lave a claim for any unpaid rent ....").

94. Id.

95. See id. Realizing that FIRREA is explicit in precluding recovery, lessors unwilling to admit defeat often resort to claims that repudiations were ineffective due to the agencies' failure to observe certain formalities, such as FIRREA's requirement that repudiation take place within a "reasonable period" of time. See, e.g., cases cited supra note 29 and accompanying text. For the most part, lessors have also been unsuccessful in challenging repudiation on this ground. $I d$.

96. 979 F.2d 609 (7th Cir. 1992).

97. See also Resolution Trust Corp. v. Ford Motor Corp., 30 F.3d 1384 (11th Cir. 1994), a case involving the repndiation of a lease of computer equipment froin Burroughs 
Concordia Federal Bank leased computer equipment from Unisys pledging securities as collateral for its lease obligation. ${ }^{98}$ Concordia later became insolvent and the RTC as receiver repudiated the lease. ${ }^{99}$ The court disallowed Unisys' claim, stating that FIRREA was "explicit in cutting off the lessor's right to obtain damages" resultimg from the repudiation of a lease. ${ }^{100}$

Unisys argued that, despite FIRREA's general disallowance of damages in section 1821(e)(4), it was entitled to satisfy its claim from the securities in which it held a security interest. ${ }^{101}$ Unisys attempted to rely on section 1821(e)(11), which states that "[n]o provision of this subsection ... shall be construed as permitting the avoidance of any legally enforceable or perfected security interest." 102 The court stated, "That claim is dead by operation of the statute, and when [the claim] died the securities pledged to its satisfaction became the unencumbered assets of the receivered savings bank." ${ }^{103}$ This case nuakes it clear that those who have leased property to failed depository institutions are not protected by security interests im the institutions' assets. The initial and dispositive inquiry is whether the lessor has a valid claim under FIRREA; typically, the answer is no. As the court explamed, "If the claim disappears-poof! the hen is gone." 104

FIRREA's complete extinguishment of all claims other than those for back rent undoubtedly comes as an unpleasant surprise to lessors who, having received security interests in institutions' assets, felt confident that their contract rights would be protected. In fact, had these lessors been dealing with anyone other than insolvent depository institutions, their rights would have been protected. Under traditional contract law, if a bank were to breach its lease agreenient prior to entering receivership, it would most likely be hable for damages to its lessor in an amount equal to the difference between the value of the rental payments remaining and the market rental rate at the tinie of the breach. ${ }^{105}$ Alternatively,

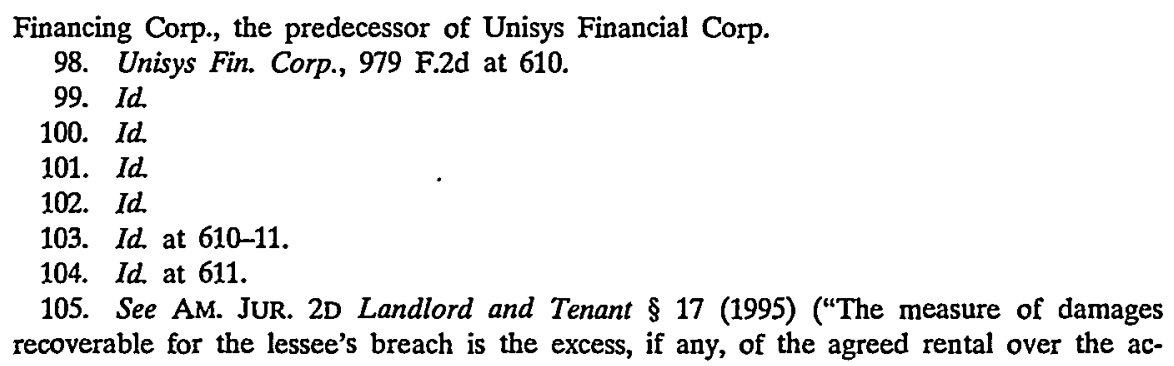


the lessor would be entitled to the amount of hquidated damages stipulated in the lease agreement. ${ }^{106}$

Likewise, the rights of lessors who have contracted with insolvent parties other than financial institutions are protected by the Bankruptcy Code. As in the case of enployment contracts, the Code does limit the amount of damages resulting from breach of an agreement to lease real property. ${ }^{107}$ Damages are first determined with reference to nonbankruptcy $l \mathrm{aw}^{108}$ and are then limited to one year's rent under the agreement. ${ }^{109}$. If more than six and two-thirds years remain under the lease, the claim is limited to rent for $15 \%$ of the remaining term of the lease, not to exceed three years rent. ${ }^{110}$ It is important to note, however, that these limits apply only to the lease of real property, whereas FIRREA disallows claims for damages resulting from the repudiation of both real and personal property. ${ }^{111}$ For example, because Unisys leased personal property, it would have had a claim for the full amount of damages allowable under traditional contract law had it dealt with an insolvent party other than a financial institution. As was true in the case of bank and thrift employees, a great and seemingly inequitable disparity exists between the treatment of lessors under FIRREA and the treatment of lessors under contract and bankruptcy laws.

\section{Recovery For Violation of an Agreement not to Compete}

The U.S. District Court for the District of Columbia had its task cut out for it when it addressed in Citibank (South Dakota),

tual rental value of the premises ....").

106. See id. § 18 ("Provisions for liquidated damages in agreements or contracts for a lease are generally enforceable."); see generally RESTATEMENT (SECOND) OF CONTRACTS $\S 356 \mathrm{cmt}$. a ("The parties to a contract may effectively provide in advance the damages that are payable in the event of breach so long as the provision does not disregard the principle of compensation.").

107. 11 U.S.C. \& 502(b)(6) (1994).

108. TREISTER ET AL, supra note 49, at 239.

109. Id: 11 U.S.C. \& 502(b)(6). Unlike the case of employment contracts, it is not clear what justification underlies this cap on damages. See BAIRD, supra note 45 , at 93 ("The usual justification for capping a landlord's damages is that they are hard to measure, but this justification is not sound.").

110. 11 U.S.C. \& 502(b)(6).

111. See Resolution Trust Corp. v. Ford Motor Credit Corp., 30 F.3d 1384, 1389 (11th Cir. 1994) ("The damage provisions for repudiated leases in Section 1821(e)(4) give no indication that they do not apply equally to all types of leases."). 
N.A. v. FDIC the question of whether the FDIC's repudiation of a non-compete agreement gives rise to a claim for "actual direct compensatory damages."112 Not only was the court faced with the difficult task of placing a inonetary value on an injury for which courts have traditionally agreed that money is an inadequate remedy, ${ }^{113}$ but it was required to do so within the framework of FIRREA's restrictive damage provisions. ${ }^{114}$ This district court is the only court that has grappled with this unique issue.

Citibank sought to recover damages resulting from the FDIC's repudiation of an agreement not to compete entered into between Citibank and Bank of New England, N.A., The Connecticut Bank and Trust Company, N.A., and Maine National Bank ("BNE Banks"). ${ }^{15}$ Citibank had purchased the credit card businesses of the BNE Banks along with an agreement by the BNE Banks not to solicit former credit card customers for a period of four years. ${ }^{116}$ The FDIC, as receiver, subsequently sold the assets of the BNE Banks to Fleet/Norstar Financial Corporation unencumbered by the non-compete provision and formally repudiated the agreement witli Citibank. ${ }^{117}$ Fleet then proceeded to compete with Citibank for its credit card business. ${ }^{118}$

On the FDIC's motion for reconsideration, the district court held that Citibank could recover only if it could show that it had suffered "actual damages" as a result of the repudiation. ${ }^{119}$ In

112. Citibank (South Dakota), N.A. v. FDIC, 827 F. Supp. 789 (D.D.C. 1993) (quoting 12 U.S.C. \& 1821 (1988)), motion for recons. granted in part and denied in part, $857 \mathrm{~F}$. Supp. 976 (D.D.C. 1994).

113. See Restatement (SECOND) of Contracts § 357 intro. note (1981) ("Courts have been increasingly willing to order performance in a wide variety of cases involving .... covenants not to compete."); see also Citibank, 827 F. Supp. at 793 ("No FIRREA case has addressed whether banking law considers non-compete provisions to be valuable assets.").

114. See Citibank, 827 F. Supp. at 792 ("To succeed, Citibank's claim must overcome the damage limitations codified in $\S 1821(\mathrm{e})(3)(\mathrm{B})$, which allow only 'actual direct compensatory danages' .... Defendants concede that Citibank's claim is compensatory. However, defendants clain that Citibank's damages are not 'actual direct coinpensatory damages,' but rather are damages for lost profit or opportunity.").

115. Citibank (South Dakota) v. FDIC, 857 F. Supp. 976, 978 (D.D.C. 1994). The district court issued two opimons-one which meinorialized the court's bench opinion and another on motion for reconsideration. The court changed its holding only with regard to the appropriate measure of damages.

116. Id

117. Id. at 979.

118. Id.

119. Id. at $982-83$. 
determining whether the repudiation gave rise to actual damages, the court held that it would be dispositive whether the BNE Banks' assets were transferred to Fleet as a "going concern."120 The court noted that, unless the FDIC transferred an entity to Fleet that was capable of competing with Citibank, "actual damages" would be zero. ${ }^{121}$ If, however, the BNE Banks' assets were transferred as a "going concern," the appropriate measure of damages would be "coextensive with the increased competitive capacity of Fleet attributable to the FDIC's transfer of the BNE Bank assets and liabilities without the encumbrance of the non-compete provision."122 The court elaborated on this measure of damages, stating that "[t]he increased competitive capacity of Fleet is not to be confused with any mcreased competitive activity by Fleet."123 The court further stated that "[i]t is irrelevant whether Fleet actually has used or will use the assets and habilities it has assumed in competition with Citibank." 124

This measure of damages is not the same as the method approved by the court in its first opmion, which memorialized the court's bench opinion. The court had originally assented to Citibank's calculation of damages as "the present value of the amount it paid for the non-compete provision which the FDIC later repudiated." 125 The court had stated, "As in the case of any intangible asset, appraisal may involve calculating the difference in value between the performance promised and the performance received." Although this calculation is far from simphistic, it is manageable. The present value of a known purchase price is far more easily determined than an amount "coextensive with the increased competitive capacity attributable to the FDIC's transfer of the BNE assets and liabilities without the encumbrance of the non-compete provision." 127 In throwing yet another factor into the equation-namely the possibility that the assets transferred were not "the entities whose non-competition Citibank sought to

120. Id. at 983 .

121. Id.

122. Id.

123. Id. at 983 n.8.

124. Id.

125. Citibank (South Dakota), N.A. v. FDIC, 827 F. Supp. 789, 793 (D.D.C. 1993), motion for recons. granted in part and denied in part, 857 F. Supp. 976 (D.D.C. 1994).

126. Id.

127. Citibank, 857 F. Supp. at 983. 
ensure"128 - the court greatly increased the complexity of the damage calculation. Just how much Citibank will eventually recover of the $\$ 44$ million in damages it sought, however, remains unclear. What is clear is that tailoring a remedy to comply with FIRREA's requirement that damages be "actual" is not an easy task.

Even when not faced with a complicating factor such as FIRREA's damage limitations, courts have traditionally viewed monetary damages as an inadequate remedy for violation of a non-compete agreement. ${ }^{129}$ A plaintiff is normally entitled to equitable rehef such as an injunction requiring the other party to comply with the agreement. ${ }^{130}$ Because of the inherent difficulty in placing a monetary value on the claims that are ordinarily enforceable in a court of equity, several courts have held that contracts such as non-compete agreements are not subject to rejection in bankruptcy. ${ }^{131}$ Because debtors cannot reject these claims, the agreements are enforceable and the other party to the agreement inay seek equitable relief-namely an injunction to prevent the debtor from engaging in competition.

Soine courts have, however, permitted rejection of non-compete agreements in bankruptcy, but only when these agreements are a part of a larger executory contract such as a franchise agreement on the theory that a debtor inust assume or reject a contract in its entirety. ${ }^{132}$ Courts following this approach have awarded

\section{Id. at 984.}

129. See RESTATEMENT (SECOND) CONTRACTS $\S 357$ intro. note (1981) ("Courts have been increasingly willing to order performance in a wide variety of cases involving ... covenants not to compete.").

130. See id. ("[A]n injunction against breach of a contract duty will be granted ... . if (a) the duty is one of forbearance ...."). Section 357 , illus. 2 , gives the breach of a non-compete agreement as an example of a situation in which an injunction is an appropriate remedy. Id.

131. See, e.g., Fellerman \& Cohen Realty Corp. v. Clinical Plus, Inc. (In re Hirschhom), 156 B.R. 379, 388 (Bankr. E.D.N.Y. 1993) ("non-compete clause emerges unscathed following the rejection of the lease"); In re Docktor Pet Ctrs., Inc., 1992 Bankr. LEXIS 1151, at *15 (Bankr. D. Mass July 22, 1992) ("[T]he non-competition clauses contained in the 'wind-down' provisions of the franchisee agreements continue to be enforceable."), vacated and remanded on other grounds, Ralls v. Docktor Pet Ctrs., Inc., 177 B.R. 420 (D. Mass. 1995); see also Carstens Health Indus. v. Cooper (In re Cooper), 47 B.R. 842 (Bankr. W.D. Mo. 1985) (holding that restrictive covenaut in einployment agreement that prevented solicitation of former chents or employees could not be rejected).

132. See, e.g., Silk Plants, Etc. Franchise Sys., Inc. v. Register (In re Register), 95 B.R. 73, 74-75 (Bankr. M.D. Tenn), affd, 100 B.R. 360, 362 (M.D. Tenn. 1989); Burger 
creditors a monetary claim for any damages resulting from the rejection of the agreement. ${ }^{133}$ Some courts following this approach have nevertheless held that non-compete agreements cannot be rejected if they are part of the nonexecutory portion of a larger agreement, thereby limiting the number of cases in which it is necessary to determine monetary damages. ${ }^{134}$ The remedies available under contract law and bankruptcy law are therefore often the same-equitable relief.

A bankruptcy court, applying either of the approaches discussed above ${ }^{135}$ to the facts of Citibank ${ }^{136}$ would not permit the debtor to reject the non-compete agreement. Under either traditional contract or bankruptcy law, Citibank would have been entitled to equitable rehef, specifically an injunction preventing the FDIC from transferring the BNE Bank assets unencumbered by the non-compete provisions. ${ }^{137}$ This is the only remedy that can truly be viewed as making Citibank whole. In contrast, under FIRREA, Citibank is limited to monetary damages and can recover only if it can uneet the difficult challenge of proving that it has suffered "actual" damage from the repudiation of the agreeinent. ${ }^{138}$ Once again, the remedies available under FIRREA fall far sliort of those available under either contract or bankruptcy laws.

King Corp. v. Rovine Corp. (In re Rovine Corp.), 6 B.R. 661, 666 (Bankr. W.D. Tenn. 1980).

133. Silk Plants, 95 B.R. at 74-75; Burger King, 6 B.R. at 666-67.

134. For example, assume that a debtor sold a business along with an agreement not to compete and an executory promise to aid the purchaser in selling any slow-moving inventory. The court would view the agreement not to compete as part of the nonexecutory contract to sell the business rather than part of the ancillary agreement to help sell the inventory and not allow rejection of the agreement not to compete. See In $r e$ Cutters, Inc., 104 B.R. 886, 890 (Bankr. M.D. Tenn. 1989) (distinguishing In re Register, 95 B.R. at 74-75). For a thorough discussion of the rejection of covenants not to compete in bankruptcy, see Jonathan H. Moss, Has Bankruptcy Forgotten the Restrictive Covenant? A Disturbing Trend for Franchise Systems, 10 BANKR. DEV. J. 237 (1994).

135. The agreement not to compete in Citibank was not part of a larger executory contract.

136. 857 F. Supp. 976 (D.D.C. 1994).

137. See supra text accompanying notes 129-131.

138. See supra text accompanying notes 119-124. 


\section{AN EXPLANATION FOR CONGRESS'S LIMITATION of CONTRACT CREDITORS' ClaIMS}

The sharp contrast between the rights of creditors under FIRREA and the rights of creditors under both traditional contract law and bankruptcy law makes one wonder what could possibly justify the difference. Are FIRREA's limitations on contract claims necessary to protect depositors of failed banks and thrifts? The answer is no. The FDIC insures deposits up to $\$ 100,000$, regardless of whether there are sufficient assets to satisfy the claims of both creditors and depositors. ${ }^{139}$ Even uninsured deposits, those above $\$ 100,000$, are fully protected in over half of all bank failures. ${ }^{140}$ On the contrary, FIRREA's limitations on contract claims are an attempt by Congress to maximize the recovery of the single largest creditor of insolvent banks and thrifts-the United States government.

\section{A. FIRREA's Pre-1993 Distribution Scheme Provided an Incentive for Congress to Limit Contract Creditors' Claims}

An examination of the scheme by which the assets of failed financial institutions were distributed under FIRREA prior to 1993 reveals that the government stood to gain a great deal by reducing contract creditors' clains. As originally passed in 1989, FIRREA provided for the pro rata distribution of the assets of insolvent institutions. ${ }^{141}$ General creditors and depositors shared in the distribution of receivership assets on a pro rata basis according to the value of their claims. ${ }^{142}$ When a bank fails, the FDIC, as the insurer of the bank and thrift deposits, pays depositors and acts as a subrogee to their claims. ${ }^{143}$ In the event the habilities of a failed

139. See 12 U.S.C. \& 1821(a)(1)(A)-(B) (1994).

140. John L. Douglas, Depositor Preference May Harm Banks, NAT'L L.J., Aug. 23, 1993, at 18. Even in cases in which uninsured deposits are not fully covered, the FDIC provides "uninsured depositors with immediate access to a significant portion of their funds." Id. (citation omitted); see 12 U.S.C. $\S 1823(\mathrm{~d})(4)$.

141. 12 U.S.C. $\$ 1821(\mathrm{~d})(11)(\mathrm{A})$ ("The receiver shall . . (ii) pay to depositors and other creditors the net amounts available for distribution to them.").

142. See id.

143. Id. ("The receiver shall-(i) retain for the account of the [FDIC] such portion of the anounts realized from any liquidation as the [FDIC] may be entitled to receive in connection with the subrogation of the claims of depositors ....."). 
bank or thrift exceeded its assets, all creditors, including the FDIC, would "suffer soine of the pain of the failure."144

The advantage to the FDIC from limiting the claims of nondepositor creditors then becones clear. As the First Circuit acknowledged,

[T] he legislators knew that ... the government's own liability (to insured depositors) would be effectively increased to the extent that remaining assets went to contract-claim creditors of the bank rather than to the government (as the subrogee for the insured depositors whom the FDIC compensated directly). It is thus not surprising that Congress might wish to disallow certain damage claims deemed less worthy than other claims. ${ }^{145}$

In addition to reducing the number of general creditors with whom the FDIC would share proportionately, FIRREA's damage provisions also limited or reduced the claims of soine secured creditors whose claims would have had priority over those of general creditors such as the FDIC. ${ }^{146}$

It is less clear how Congress determined some claims to be less worthy. As discussed previously, the means by which Congress chose to limit claims is an abrogation of both traditional contract and bankruptcy laws. ${ }^{147}$ Some commentators have gone so far as to suggest that "many legislators and congressional staffers probably did not understand FIRREA's potential impact on S\&L creditors. Considering how many legislators are lawyers, it would be strange and unexpected if they knowingly had structured a system that ... accords creditors such [meager] rights and that contrasts so sharply with the federal bankruptcy laws." 148 In its haste to secure as large a recovery as possible for the government, Congress forgot that it is also the "purpose of insolvency statutes to preserve the rights existing at the time of insolvency."149

144. Douglas, supra note 140 , at 22 .

145. Howell v. FDIC, 986 F.2d 569, 572 (1st Cir. 1993).

146. FIRREA, as enacted in 1989, states: "No provision of this subsection shall be construed as permitting the avoidance of any legally enforceable or perfected security interest . . . " 12 U.S.C. $\S 1821(\mathrm{e})(11)$ (1994).

147. See discussion supra Part II.

148. Leibold, supra note 28 , at 22. Arthur Leibold, Jr. is the former general counsel of the Federal Home Loan Bank Board, the Federal Savings and Loan Insurance Corp., and the Federal Home Loan Mortgage Corp. Id.

149. See Office and Professional Employees Int'l Umion, Local 2 v. FDIC, 27 F.3d 598, 604-05 (D.C. Cir. 1994) (quoting FDIC v. Liberty Nat'l Bank, 806 F.2d 961, 965 
B. The 1993 Depositor Preference Provisions Make Limitations on Creditors' Claims Unnecessary

Although the government's desire to secure a larger recovery for itself is arguably an unjustified basis for curtailing creditors' rights, it does explain FIRREA's harsh treatment of creditors' claims. FIRREA's damage limitations may be inequitable and difficult for courts to apply, but they did serve Congress's goal of maximizing the FDIC's recovery. A 1993 amendment to the Federal Deposit Insurance Act establishing a national depositor preference for federal depository institutions has made it unnecessary for the FDIC to limit creditors' claims. The ainendment replaced FIRREA's pro rata distribution scheme with a scheme that places the FDIC alone at the head of the line to receive bank assets. ${ }^{150}$

The depositor-preference provisions provide for the payment of claims in accordance with a list of priorities. ${ }^{151}$ All deposit liabilities must be paid before the general creditors of a financial institution receive anything. ${ }^{152}$ As mentioned previously, the FDIC, as insurer of deposit hability, pays depositors' claims regardless of whether the assets of the institution are sufficient to cover its habilities. ${ }^{153}$ The FDIC is then subrogated to these claims and stands $m$ the shoes of the depositors in this priority scheme. ${ }^{154}$ As Jolin L. Douglas, former counsel to the FDIC pointed out, "Depositor preference has little to do with whether depositors are paid when a bank fails .... A more apt description might be 'FDIC preference.' '155

(10th Cir. 1986)).

150. Omnibus Budget Reconciliation Act of 1993, Pub. L. No. 103-66, § 3001, 107 Stat. 312, 336 (amending 12 U.S.C. $§ 1821$ (d)(11)(A) (1994)). In 1993, almost half of the states already had depositor-preference provisions in place. Douglas, supra note 140, at 18. This number had greatly increased since the passage of FIRREA in 1989. See Leibold, supra note 28 , at 22 (noting that there were eight depositor preference states im 1990). Nevertheless, it is predicted that the implementation of a national depositor preference will "profoundly affect financial institutions and their creditors." Douglas, supra note 140 , at 18. This is partly due to the fact that, in 1993, "few of the major state banks [were] located in states where depositor-preference schemes [were] in place." Id.

151. See Omnibus Budget Reconciliation Act $\$ 3001$.

152. See id.

153. See supra notes $139-40$ and accompanying text.

154. See supra note 143 and accompanying text.

155. Douglas, supra note 140, at 18; see also New Law Increases Risks to Creditors of US Depository Institutions, INVESTORS CHRONICLE, Oct. 22, 1993, at Finance Section [hereinafter INVESTORS CHRONICLE] ("[T]he FDIC is the primary beneficiary of the depositor preference provisions."). 
Creditors have therefore been dealt a double blow. First, Congress limited creditors' claims for damages resulting from the repudiation of contracts. Congress then ensured that creditors would receive nothing on these truncated claims until the FDIC had fully recovered its share. Arthur Leibold, Jr., former general counsel for the Federal Savings and Loan Insurance Corporation, appears to have been correct in 1990 when he stated that "the government seems to have forsaken the goal of providing equitable results for thrifts and their creditors in favor of maximizing returns or lowering costs for itself." ${ }^{156}$ That observation would become even more true with the implementation of a national depositor preference in 1993. According to estimates by the Congressional Budget Office, depositor preference will save the FDIC-and conversely, cost creditors-approximately $\$ 490$ million between 1994 and 1998. ${ }^{157}$

The inequity of punishing creditors who have dealt with financial institutions at arms length becomes even clearer when one considers who is in the better position-bank regulators or creditors-to momitor the behavior of depository institutions. ${ }^{158}$

[A] contracting party can look at published financial statements, but it cannot review a bank's or thrift's loan portfolio, interview the institution's managers, ascertain the adequacy of reserves or make any of the nnyriad determinations that are possible only with an in-depth examination of the bank or thrift. ${ }^{159}$

Not only are the FDIC and RTC in a better position to momitor the health of banks aud thrifts, it is their job. The Federal Deposit Insurance Corporation Improvement Act contains "prompt corrective action" provisions, which require that the FDIC and RTC "resolve the problems of insured depository institutions at the least possible long-term loss to the deposit insurance fund . . . by taking

156. Leibold, supra note 28 , at 22 ; see also Swire, supra note 47 , at 520-21. "The temptation for the [FDIC] and Congress is to push costs of the bailout off-budget and onto third parties. These incentives to be strict lead to the suspicion that the recent flurry of bank insolvency laws have been based more on pohitics than on accurate public policy." Id.

157. INVESTORS CHRONICLE, supra note 155, at Finance Section.

158. Douglas, supra note 140 , at 22 .

159. Id. Douglas also notes that creditors may not even be able to rely on the published financial statements of banks and thrifts. Id. Banks publishing high capital ratios on their balance sheet liave been known to fail. Id. Southeast Bank, N.A., for example, was reporting $\$ 400$ million in equity at the time it failed. Id. 
prompt corrective action to resolve the problems of insured depository institutions." 160 Although the agencies are required to seize an institution before its habilities exceeds its assets, depositor preference creates a "cushion" that insulates the FDIC from loss if it allows an institution's assets to deteriorate further. ${ }^{161}$ The FDIC loses nothing at the point of insolvency. It is not until the point at which assets are less than the deposit liabilities that the FDIC shares in the loss.

\section{THE EFFECTS OF FIRREA's UNNECESSARY DAMAGE LIMITATIONS ON DEPOSITORY INSTITUTIONS}

It appears that FIRREA's stringent damage provisions have outlasted their usefulness to the FDIC. Now that the FDIC is assured a full recovery on its claims before nondepositor creditors receive anything, ${ }^{162}$ there appears to be little justification for making creditors jump over the "actual direct compensatory damages" hurdle in order to recover. In fact, there is a good reason for not placing a hurdle in the way of creditors' recoveries.

Inadequately compensating the creditors of banks and thrifts increases the cost of domg busmess to financial institutions. ${ }^{163}$ If parties contracting with financial imstitutions must assume the risk that their contract rights will not be adequately protected in receivership, they will demand more favorable contract terms im return or will forego contracting with financial institutions altogether. ${ }^{164}$ In effect, contracting parties will deinand to be compensated "up front" for the possibility that they will receive nothing if the depository institution fails. ${ }^{165}$

160. 12 U.S.C. § 1831(a)(1), (2) (1994).

161. Douglas, supra note 140 , at 22 .

162. See supra notes $150-52$ and accompanying text.

163. See Anthony Baldo, Poof, the Claim Is Gone, Fin. World, May 24, 1994, at 70, 71; Douglas, supra note 140 , at 42 ; Swire, supra note 46 , at 544-51.

164. See Douglas, supra note 140 , at 22 . This problem is exacerbated by two additional factors. First, because the financial statements of banks and thrifts are often unreliable, creditors cannot accurately assess the risks of contracting with particular institutions and therefore pass increased costs on to both healthy and weak institutions. Id. Second, creditors wishing to challenge the actions of the FDIC or RTC "can gain access to courts only by bringing extraordinary suits against the government." Leibold, supra note 28 , at 22.

165. See generally RICHARD A. POSNER, ECONOMIC ANALYSIS OF THE LAW 91 (4th ed. 1992). (" $[T]$ he fundamental function of contract law . . . is to deter people from behaving opportunistically toward their contracting parties, in order to encourage the optimal timing of economic activity and (the same point) obviate costly self-protective mea- 
The addition of depositor preference provisions in 1993 has greatly increased the risks associated with contracting with financial institutions. ${ }^{166}$ These provisions alone are guaranteed to affect the way parties deal with banks and thrifts. Nevertheless, FIRREA's damage provisions continue to exacerbate these problems. Creditors of financial institutions still have a stake in ensuring that their claims survive receivership. In the best case scenario, the assets of the receivered institution will exceed its total habilities; creditors could theoretically be paid in full. FIRREA's damage limitations, however, assure that some creditors will nevertheless receive nothing for their claims. Even when the assets of an institution do not exceed its total liabilities, creditors will receive what remains on a pro rata basis according to their claims as long as assets exceed deposit liabilities. ${ }^{167}$ In addition, all creditors have a stake in ensuring that they will be adequately compensated should the FDIC or RTC repudiate their contract while acting as a conservator for a troubled, but not necessarily insolvent, institution. ${ }^{168}$

The "prompt-corrective-action provisions,"169 which took effect in Deceinber of 1992, are designed to ensure that the best case scenario, in which assets of an institution seized by the FDIC or RTC exceed its habilities, becoines the most common scenario. These provisions create five capital categories, with institutions earning a rating ranging from "well-capitalized" to "critically undercapitalized." 170 Institutions are subject to varying sanctions depending upon their level of capitalization, including restrictions on distributing capital, paying management fees, opening branch offices, and undertaking new lines of business. ${ }^{171}$ Once an institution's capital falls to $2 \%$ of its total assets, it is considered "critically undercapitalized" and the FDIC is required to seize the institution

sures.").

166. See, e.g., INVESTORS CHRONICLE, supra note 155, at Finance Section.

167. See Douglas, supra note 140 , at 22 , for numerical exainples of the possible recoveries creditors may receive.

168. Insolvency is not the only grounds for the appointment of the FDIC as receiver. Other grounds include "[a]ny willful violation of a cease-and-desist order . . . [or] concealment of the institution's books, papers, records, or assets." 12 U.S.C. § 1821(c)(5) (D)-(E) (1994).

169. See discussion supra note 160 and accompanying text.

170. 12 U.S.C. § 18310 (b) (1994).

171. Id. § 18310 (d)-(i). 
within ninety days. ${ }^{172}$ These provisions seek to ensure that "some banks on the verge of failing [are] closed earher" and to "encourage many other weak mstitutions to take actions on their own to correct their deficiencies."173 The effect of these provisions will be to increase the assets that are available to satisfy creditors' potential claims.

Because the claims of secured creditors are not subordinated to the claims of depositors under the 1993 depositor-preference provisions, ${ }^{174}$ removal of FIRREA's damage limitations would also create greater certainty for the secured creditors of financial institutions. For example, a creditor, such as Unisys Corporation, ${ }^{175}$ who leases property and equipinent to a financial institution would be protected by a security interest in the institution's assets rather than unpleasantly surprised to learn that its claim has been totally extmguished and that its security interest is worthless. The recovery of creditors may no longer be of great importance to the FDIC, but it is of importance to many creditors.

Courts $^{176}$ and commentators ${ }^{177}$ have both recognized that FIRREA's damage provisions have created uncertainty surrounding the contracts of financial institutions that translates into higher costs for banks and thrifts. For exaniple, inadequately compensating plaintiffs for injuries caused by the repudiation of agreenents such as non-compete provisions will serve to decrease the value of the assets of troubled institutions. ${ }^{178}$ In order for troubled banks and thrifts to maximize the return from the sale of their assets,

172. Id. \& $1831 \mathrm{o}(\mathrm{h})(3)$.

173. FDIC Board Votes For Final Regulation Goveming Shutdowns of Troubled Banks, BNA BANKING DAILY, Sept. 16, 1992, available in LEXIS, Bankg. Library, BNABD File (quoting Acting FDIC Chairman Andrew Hove).

174. 12 U.S.C. \& 1821(d)(11)(A) (1994). "[A]mounts realized from the liquidation or other resolution of any insured depository institution by any receiver . . . shall be distributed to pay claims (other than secured claims to the extent of any such security) in the following order of priority: . . (ii) Any deposit liability of the institution." Id.

175. See discussion supra notes $96-103$ and accompanying text.

176. See, e.g., Citibank (South Dakota), N.A. v. FDIC, 827 F. Supp. 789, 792 (D.D.C. 1993) (noting that leaving mjured parties uncompensated devalues the assets of troubled banks), motion for recons. granted in part and denied in part, 857 F. Supp. 976 (D.D.C. 1994).

177. See Baldo, supra note 163, at 71 ; Douglas, supra note 140 , at 22 ; see also Swire, supra note 46, at 544-51 (arguing that insolvency rules that favor the FDIC at the expense of other parties will affect the way in which many groups, including creditors and bank persounel, deal with nearly insolvent banks).

178. Citibank, 827 F. Supp. at 792. 
they must often enter into ancillary agreements such as non-compete agreements. If the purchasers of assets have no assurance that their right to enforce such agreements will be protected if the institution becomes insolvent, they will be willing to purchase assets only at a lower price. As one commentator explaimed in 1992,

In the face of such risks, these contract beneficiaries will have an incentive to grab assets before insolvency, to reduce the amount of credit extended to nearly insolvent banks, or to place a growing risk premium on doing business with the bank as it nears insolvency. These actions will hurt a bank's earnings, further increasing the likeliliood of insolvency. Contract beneficiaries will thus contribute to the "blackhole" phenomenon of a nearly insolvent bank becoining insolvent. ${ }^{179}$

The court in Citibank (South Dakota), N.A. v. FDIC recognized these risks, stating that "[l]eaving such mjured parties uncompensated would greatly affect the amount that troubled, but still solvent, banks receive for selling assets to stay afloat. The risk of uncompensated FDIC repudiation would devalue assets and raise the cost of bailout if the bank did not survive."180 Whether this court was able to fashion a re1nedy within FIRREA's "actual direct compensatory" framework that will adequately compensate Citibank is unclear. However, the court's opinion at least recognizes that trampling the contract rights of creditors is counterproductive in the long run.

Likewise, disallowing recovery under severance agreements will negatively affect the ability of financial institutions to retain employees. ${ }^{181}$ As one commentator explained,

Banks that are restructuring also must attract and retain quality employees. As the banking and thrift industries consolidate, every employee can be essential to the ultimate success of a bank or thrift. This is particularly important for institutions that are carrying out restructuring programs, are subject to formal agreements or cease and desist orders, or are under other regulatory scrutiny. ${ }^{182}$

179. Swire, supra note 46 , at 549.

180. Citibank, 827 F. Supp. at 792.

181. Robert E. Braun, How to Bulletproof Compensation Programs, THE AM. BANKER, Aug. 30, 1993, at 18.

182. Id. 
The plaintiffs in Howell v. FDIC raised these concerns, arguing that "the disallowance of promised severance pay will mean that a troubled bank cannot effectively contract to retain able officers." ${ }^{183}$ The court recognized that the plaintiffs' argument might "have some force" but felt that their argument presented "a policy question best left to Congress." 184

As discussed previously, ${ }^{185}$ Congress has in fact already responded to what were viewed as excessive compensation plans for high-level employees of bankrupt banks and thrifts by disallowing "golden parachute" payments. ${ }^{186}$ However, the reasoning employed by the courts in Howell v. FDIC ${ }^{187}$ and Hennessy $v$. $F D I C^{188}$ reaches much further and thus interferes with institutions' 'bona fide attempts to compensate employees and management officials on a modest but meaningful basis." 189 Whether or not Congress intended to disallow virtually all severance agreements, the fact remains that the courts have felt compelled by FIRREA's "actual direct compensatory" language to do so. If this was not the result that Congress intended, it could eliminate some confusion and relieve what has been a burden on troubled banking institutions by repealing FIRREA's damage provisions.

\section{CONCLUSION}

Congress is long overdue in reconsidering the wisdom of making contract creditors bear a disproportionate share of the losses resulting from bank failures. As one commentator has argued, while it may "llave a modestly positive budgetary impact," it will in the long run be "bad for banks and bad for those who deal with banks."190 Eliminating FIRREA's damage limitations and

183. 986 F.2d 569, 573 (1st Cir. 1993); see also Hennessy v. FDIC, 58 F.3d 908, 921 (3d Cir. 1995) ("[W]e are cognizant of the fact that disallowance of promised severance pay may chill a troubled bank's ability to effectively retain able employees.").

184. Howell, 986 F.2d at 574.

185. See supra notes $76-82$ and accompanying text.

186. 12 U.S.C. \& 1828(k) (1994).

187. 986 F.2d at 569.

188. 58 F.3d at 908.

189. Braun, supra note 181 , at 19.

190. Douglas, supra note 140 , at 22 ; see also Swire, supra note 46 , at 556 ("At a minimum, the agencies should be required to make fresh showings that the rules are well tailored to actual problems and are not political efforts to avoid blame for the bailout."). 
leaving the depositor preference provisions in place will admittedly leave the lion's share of these problems unaddressed. Eliminating these limits will, however, serve a mitigating purpose and remove a relic that lias been a source of frustration for both courts and creditors. 